\author{
Dr. sc. Marija Pleić, poslijedoktorandica \\ Pravni fakultet Sveučilišta u Splitu*
}

\title{
KAZNENI PROGON I ISTRAŽIVANJE KAZNENIH DJELA PROTIV OKOLIŠA ${ }^{1}$
}

\author{
UDK: $343.1: 502 / 504$ \\ Izvorni znanstveni rad \\ Primljeno: 10.01. 2016.
}

\begin{abstract}
U radu se analiziraju pitanja vezana uz kazneni progon i istraživanje kaznenih djela protiv okoliša, posebice s aspekta zakonodavnih i praktičnih aktivnosti tijela Europske unije, Eurojusta i Europola na području kaznenopravne zaštite okoliša. Zakonodavstvo koje regulira zaštitu okoliša opsežno je i složeno te zahtijeva stručna i specijalizirana znanja tijela kaznenog progona u svim stadijima kaznenog postupka. Premda hrvatsko kazneno zakonodavstvo postavlja visok stupanj zaštite okoliša, još uvijek nije dovoljno ni kod upravnih tijela ni kod tijela kaznenog progona razvijena svijest o opasnostima i teškim posljedicama ove vrste kriminala. Na razini EU ukazuje se potreba za boljom i koordiniranom prekograničnom suradnjom.
\end{abstract}

\section{Ključne riječi: kaznena djela protiv okoliša, kazneni progon, istraživanje, prekogranična suradnja}

\section{UVOD}

Zaštita okoliša ostvaruje se primarno putem upravnog prava te građanskog prava, a kazneno pravo dolazi kao ultima ratio kod najtežih povreda okoliša koje zahtijevaju odvraćajuće kaznenopravne sankcije. ${ }^{2} \mathrm{~S}$ obzirom na specifičnost objekta zaštite, supsidijarnost, fragmentarnost i akcesornost, kao temeljne značajke kaznenog prava, posebno su izražene kod zaštite okoliša. ${ }^{3}$ Zakonski opisi kaznenih djela protiv okoliša, bilo izravno bilo neizravno, upućuju na opsežno zakonodavstvo zaštite okoliša što podrazumijeva poznavanje tih propisa od strane tijela kaznenog progona i kaznenog postupka.

$1 *$ Dr. sc. Marija Pleić, poslijedoktorandica na Katedri za kazneno procesno pravo Pravnog fakulteta Sveučilišta u Splitu, Domovinskog rata 8,21000 Split, e-mail: marija.pleic@pravst.hr

Ovaj rad predstavlja dio referata „Environmental protection through criminal law: special criminal offences of endangering the environment" što ga je autorica izlagala zajedno s dr. sc. Ivanom Vukušićem na međunarodnom simpoziju „Vlasnička prava, nejednakost, sudjelovanje potrošača u financiranju, obnovljiva energija i zaštita okoliša“, održanom na Pravnom fakultetu Sveučilišta u Splitu 25. - 26. svibnja 2015. godine.

2 Kaznene sankcije za onečišćenje mogu se pronaći već u 14. st., kada je kralj Eduard I. kraljevskom naredbom zabranio spaljivanje ugljena u Londonu kako bi smanjio količinu dima u zraku, a prekršitelji ove naredbe mogli su biti osuđeni na smrt. Situ, Y.; Emmons, D.: Environmental Crime, The Criminal Justice System's Role in Protecting the Environment, Sage Publications, Inc., 2000., str. 22., Također: Allaby, M.: Fog, Smoke and Posined Rain, New York, 2013., str. 185.

3 Opš. Cvitanović, L.: „Kaznena djela protiv okoliša“ u: Novoselec, P. (ur.): Posebni dio kaznenog prava, prvo izdanje, Zagreb, 2007., str. 274. 
Recital Direktive 2008/99/EZ o kaznenopravnoj zaštiti okoliša ${ }^{4}$ pruža polazište za definiranje kaznenih djela protiv okoliša navodeći da su, radi učinkovite zaštite okoliša, odvraćajuće sankcije potrebne za djelatnosti koje štete okolišu, a koje obično uzrokuju ili bi mogle uzrokovati značajnu štetu za zrak, uključujući i stratosferu, za tlo, vodu, životinje ili biljke, uključujući i štetu za očuvanje vrsta. Izvješće Eurojusta o Strateškom projektu o ekološkom kriminalu definira ova kaznena djela kao ozbiljni kriminal često počinjen od strane grupa organiziranog kriminala, koji utječe na društvo u cjelini budući da se njegov utjecaj ne odražava samo na zdravlju ljudi i životinja već i na kvaliteti zraka, tla i vode. ${ }^{5}$

Kaznena djela protiv okoliša danas predstavljaju jedno od najprofitabilnijih i najbrže rastućih područja međunarodne kriminalne aktivnosti. Kao temeljni pokretači ove vrste kriminala ističu se rastuće globalne potrebe za prirodnim resursima, ekonomska korist koja uključuje mogućnost visokog profita te regulatorne manjkavosti kako $\mathrm{u}$ nacionalnom tako i $\mathrm{u}$ međunarodnom zakonodavstvu, ali i u njegovu izvršenju. ${ }^{6}$ Ekološki kriminal vrlo je često povezan uz kaznena djela prijevare te općenito gospodarski kriminal.

Nedovoljno razvijena svijest javnosti o opasnosti i posljedicama ovih kaznenih djela rezultira visokom tamnom brojkom, a tome doprinosi i činjenica da se radi u pravilu o djelima bez neposredne žrtve te nadležna tijela smatraju ovu vrstu kriminaliteta manje važnim u odnosu na tradicionalni kriminalitet. ${ }^{7}$ Sve navedeno čini kaznena djela protiv okoliša kriminalom koji omogućuje visok profit uz minimalni rizik (tzv. high profit - low risk) što otvara široke mogućnosti djelovanju organiziranog kriminala.

U ovom će se radu analizirati kaznenopravna zaštita okoliša s njezinog kaznenoprocesnog aspekta odnosno posebnosti i poteškoće u vršenju kaznenog progona kaznenih djela protiv okoliša. Naglasak u radu bit će na novim tendencijama i aktivnostima tijela Europske unije u borbi protiv kaznenih djela protiv okoliša. Pojačana aktivnost međunarodne zajednice, napose Europske unije posljedica je sve češćeg i sve izraženijeg prekograničnog elementa kao i uključenosti organiziranog kriminala kod ove vrste kaznenih djela koja stoga zahtijeva i odgovarajuću reakciju i suradnju država članica EU kao i trećih država.

Nakon uvoda, slijedi poglavlje o zakonodavnim i praktičnim aktivnostima Europske unije na području kaznenopravne zaštite okoliša. Treće poglavlje razrađuje posebnosti i poteškoće u kaznenom progonu i istraživanju kaznenih djela protiv okoliša uočenih na području Europske unije, a u četvrtom se poglavlju

4 Direktiva 2008/99/EZ Europskog parlamenta i Vijeća od 19. studenoga 2008. o zaštiti okoliša putem kaznenog prava, SL EU L 328/28.

5 Eurojust: Strategic Project on Environmental Crime, Report, October 2014., str. 5. (Dalje: Strategic Project on Environmental Crime, Report). Dostupno na: http://www.eurojust.europa.eu/doclibrary/ Eurojust-framework/Pages/casework.aspx

6 Pereira, R. M.: Environmental Criminal Liability and Enforcement in European and International Law, Brill Nijhoff, 2015., str. 3.

7 Ibidem, str. 10. 
Dr. sc. Marija Pleić: Kazneni progon i istraživanje kaznenih djela protiv okoliša Zbornik radova Pravnog fakulteta u Splitu, god. 53, 2/2016., str. 601.-622.

izlažu značajke kaznenog progona za kaznena djela protiv okoliša u Republici Hrvatskoj nakon čega slijedi zaključak.

\section{KAZNENOPRAVNA ZAŠTITA OKOLIŠA U EUROPSKOJ UNIJI}

\subsection{Razvoj kaznenopravne zaštite okoliša u EU}

Stupanjem na snagu Jedinstvenog europskog akta 1987. godine, koji je izmijenio i dopunio Ugovor o osnivanju Europske ekonomske zajednice, zaštita okoliša dobila je svoj pravni temelj u primarnim aktima Europske unije. ${ }^{8}$ Lisabonskim je ugovorom u čl. 4.2. Ugovora o funkcioniranju Europske unije (dalje: UFEU) prvi put naveden okoliš kao područje podijeljene nadležnosti između Unije i država članica.

I prije nego što je Lisabonski ugovor u čl. 83. UFEU-a uspostavio nadležnost EU u kaznenim stvarima, postavljeno je pitanje kaznenopravne zaštite okoliša u okviru EU. Jedan od prvih koraka u tom smjeru bila je danska inicijativa za usvajanje okvirne odluke o zaštiti okoliša kaznenim pravom. Ova je Okvirna odluka9 uzela u obzir temeljne odredbe Europske konvencije o zaštiti okoliša putem kaznenog prava iz 1998. godine koja je, premda nije stupila na pravnu snagu, pružila podlogu za kasnija nastojanja Europske unije u reguliranju kaznenopravne zaštite okoliša. ${ }^{10}$ Donošenje Okvirne odluke otvorilo je pitanje može li Europska zajednica propisati državama članicama kaznene mjere s ciljem izvršenja europskog prava zaštite okoliša. Nakon dugotrajne institucionalne rasprave te dviju presuda Europskog suda pravde o opsegu nadležnosti Zajednice u području kaznenog prava, koje su otvorile vrata mogućnosti korištenja kaznenog prava u svrhe zaštite okoliša, Vijeće i Europski parlament sporazumjeli su se o tekstu direktive o zaštiti okoliša putem kaznenog prava. ${ }^{11} \mathrm{U}$ presudi koja se smatra najdalekosežnijom odlukom za područje kaznenog prava u dotadašnjem razvoju Europske zajednice, ${ }^{12} \mathrm{u}$ predmetu Environmental Crime (C-176/03), Europski je sud pravde riješio sukob između spomenute Okvirne odluke o zaštiti okoliša kaznenim pravom usvojene u okviru trećeg stupa Ugovora o Europskoj uniji i Komisijinog prijedloga direktive

8 Opširnije o razvoju pravu zaštite okoliša u EU u: Koeman, N. S. J. (ur): Environmental Law in Europe, Kluwer Law International, 1999., str. 3. i dalje.

9 Okvirna odluka 2003/80/PUP od 27. siječnja 2003. o zaštiti okoliša kaznenim pravom, SL L 29, 5. 2. 2003 .

10 To je prva međunarodna konvencija koja je imala za cilj kriminalizirati ponašanja kojima se nanosi šteta okolišu. U odnosu na kazneno procesno pravo, Konvencija je predvidjela načelo teritorijalnosti, zastave broda, državljanstva te načelo aut dedere aut judicare, smjerala je olakšavanju sudjelovanja građana u kaznenim postupcima (actio popularis) te jačanju međunarodne pravosudne suradnje. Vagliasindi, G. M.: Directive 2008/99/EC on Environmental Crime and Directive 2009/123/EC on Ship-source Pollution. Study in the framework of the EFFACE research project. Catania: University of Catania, 2015., str. 7.

11 Fajardo, T.: EU Environmental Law and Environmental Crime: An Introduction. Study in the framework of the EFFACE research project, Granada: University of Granada, 2015., str. 11.

12 Opš. Đurđević, Z.: „Lisabonski ugovor: prekretnica u razvoju kaznenog prava u Europi“, Hrvatski ljetopis za kazneno pravo i praksu (Zagreb), vol. 15, broj 2/2008, str. 1100. 
vezanog uz isto pitanje u okviru prvog stupa. Sud je poništio Okvirnu odluku te obrazložio da, iako po općem pravilu kazneno pravo i kazneni postupak ne spadaju u nadležnost Zajednice, u slučajevima kada je primjena učinkovitih, razmjernih i odvraćajućih sankcija od strane nacionalnih tijela ključna mjera $u$ borbi protiv teških kaznenih djela protiv okoliša, Zajednica može propisati mjere koje se odnose na kazneno pravo država članica a koje smatra potrebnima kako bi se osigurala učinkovitost odredbi za zaštitu okoliša. ${ }^{13} \mathrm{U}$ presudi u predmetu Ship-source pollution Sud je podcrtao doseg nadležnosti Zajednice u primjeni kaznenog prava u zaštiti okoliša i, naglašavajući svoj prethodno izneseni stav, naveo da određivanje vrste i visine kaznenopravnih sankcija ne spada u nadležnost Zajednice. ${ }^{14}$ Ovo se ograničenje u pogledu određivanja kaznenopravnih sankcija odrazilo na konačni prijedlog Direktive o zaštiti okoliša putem kaznenog prava. ${ }^{15}$

Direktiva 2008/99/EZ Europskog parlamenta i Vijeća od 19. studenoga 2008. o zaštiti okoliša putem kaznenog prava navodi popis kaznenih djela protiv okoliša koje države članice moraju unijeti u svoja nacionalna zakonodavstva pod uvjetom da su počinjena s namjerom ili iz krajnje nepažnje (intentionally or with at least serious negligence) te zahtijeva od država članica da za ta kaznena djela usvoje učinkovite, razmjerne i odvraćajuće sankcije. U zakonodavstvo Republike Hrvatske transponirana je putem novog Kaznenog zakona koji je na snagu stupio 1. siječnja 2013. ${ }^{16}$ Studija o implementaciji ove Direktive u državama članicama EU pokazala je da postoje problemi u pogledu usklađivanja i definiranja pojedinih pojmova iz Direktive, primjerice, substantial damage, non-negligible quantity, deterioration i sl. kao i da postoji neusklađenost u pogledu težine sankcija za pojedina kaznena djela što može ugroziti međunarodnu suradnju u slučaju ako isto kazneno djelo nije kažnjivo kaznom zatvora od godine dana u obje države članice EU. ${ }^{17}$

Direktiva o zaštiti okoliša putem kaznenog prava ne sadrži odredbe koje bi se odnosile na kazneni postupak povodom kaznenih djela protiv okoliša niti se dotiče nadležnosti tužitelja i suda u tim postupcima. Međutim, premda se izravno ne dotiče kaznenog postupka, zahtjev za primjenom odvraćajućih, razmjernih i

13 Presuda Suda (veliko vijeće) od 13. rujna 2005., Komisija Europskih zajednica protiv Vijeća Europske unije. Predmet C-176/03, recital 47. Sud je u ovoj presudi otvorio novi pristup ka načelu učinkovitosti, tvrdeći da EU ima pravo regulirati kazneno pravo u ime pune učinkovitosti prava Zajednice u provođenju zaštite okoliša. Načelo učinkovitosti je korišteno kao konstitucionalni koncept za opravdanje zakonodavstva na razini EU. Tako Herlin-Karnell, E.: „,What Principles Drive (or Should Drive) European Criminal Law?“, German Law Journal, Vol. 11, 2010., str. 1122.

14 Presuda Suda (veliko vijeće) od 23. listopada 2007. Komisija Europskih zajednica protiv Vijeća Europske unije. Predmet C-440/05. O učinku ovih dviju presuda Europskog suda pravde na kaznenopravnu nadležnost država članica, Zajednice i Unije, opš. Đurđević, Z., op. cit. (bilj. 12), str. 1103.

15 Tako Fajardo, T., op. cit. (bilj. 11), str. 8-9. Također: Pereira, R. M., op. cit. (bilj. 6), str. 32-33.

16 Kazneni zakon, Narodne novine 125/11, 144/12, 56/15, 61/15.

17 Council of The European Union: Report of the Strategic Meeting towards an enhanced coordination of environmental crime prosecutions across the EU: The role of Eurojust, 8101/14, Brussels, 24 March 2014., str. 7. (Dalje: Report of the Strategic meeting...) Dostupno na: http://eurojust.europa.eu/doclibrary/ Eurojust-framework/strategic-meetings-and-seminars/Pages/topical-events-reports.aspx 
učinkovitih sankcija podrazumijeva učinkoviti progon za kaznena djela protiv okoliša te kazneni postupak u kojemu će se takve sankcije i izreći.

Prepoznajući rastuću opasnost od kaznenih djela protiv okoliša s međunarodnim elementom te uočavajući poteškoće u otkrivanju i kaznenom progonu tih kaznenih djela, svoju su aktivnost u smjeru koordinacije i poboljšanja suradnje tijela kaznenog progona država članica intenzivirala tijela Europske unije, Eurojust i Europol o čemu će više riječi biti u nastavku.

\subsection{Uloga Eurojusta u kaznenopravnoj zaštiti okoliša}

Eurojust je tijelo Europske unije s pravnom osobnošću osnovano Odlukom Vijeća 2002/187/PUP od 28. veljače 2002. g. o osnivanju Eurojusta s ciljem jačanja borbe protiv teških kaznenih djela. ${ }^{18}$ Eurojust ima za cilj, u kontekstu istraga i kaznenih progona koji se tiču dviju ili više država članica u vezi s teškim oblicima kriminala, posebno kada je organiziran, među ostalim, poticati i unapređivati među nadležnim tijelima država članica koordinaciju istraga i kaznenih progona u državama članicama, unaprijediti suradnju te podupirati nadležna tijela država članica i na druge načine kako bi njihove istrage i kazneni progoni bili djelotvorniji. Svaka država članica upućuje jednog nacionalnog člana u Eurojust u skladu sa svojim pravnim sustavom, a koji je tužitelj, sudac ili policijski službenik s ekvivalentnim nadležnostima. Eurojust može izvršavati svoje zadaće na dva načina: putem jednog ili više svojih nacionalnih članova te djelujući kao Kolegij koji se sastoji od svih nacionalnih članova. Eurojust može postavljati nadležnim tijelima država članica različite zahtjeve, može tražiti pokretanje istrage ili progon, ili pak može tražiti od tijela jedne države članice da prihvati činjenicu da je nadležno tijelo druge članice u boljem položaju vršiti kazneni progon, može uspostaviti zajednički istražni tim i osigurati potrebne informacije. Članak 6. Odluke o Eurojustu navodi niz inicijativa koje Eurojust može poduzeti s ciljem poticanja istraga i suradnje država članica, stavljajući naglasak na koordiniranju kaznenog progona. Osim onih aktivnosti koje može poduzeti preko pojedinih nacionalnih članova, Eurojust putem Kolegija može pomagati Europolu, posebice dajući mu mišljenja temeljena na analizama koje je Europol proveo. ${ }^{19}$

Kada je riječ o ekološkom kriminalu, Eurojust ima važnu ulogu promicanja suradnje i koordinacije između nadležnih sudskih tijela u istraživanju i progonu ozbiljnih kaznenih djela protiv okoliša s prekograničnim elementom. Eurojust je 2013. godine pokrenuo Strateški projekt o kaznenim djelima protiv okoliša, vođen intrigantnim paradoksom da raste svijest o kaznenim djelima protiv okoliša kao ozbiljnom kriminalu koji u pravilu uključuje prekograničnu dimenziju i organizirani kriminal ali se to istovremeno ne odražava u statističkim podacima o progonu ovih kaznenih djela. ${ }^{20}$ Tri područja koja su bila u posebnom žarištu

18 Ova je Odluka promijenjena Odlukom Vijeća 2003/659/PUP od 18. lipnja 2003. te Odlukom Vijeća 2009/426/PUP od 16. prosinca 2008. o jačanju Eurojusta (Dalje: Odluka o Eurojustu).

19 Opš. Klip, A.: European Criminal Law, Inersentia, $2^{\text {nd }}$ edition, 2012., str. 449-451.

20 Strategic Project on Environmental Crime, Report, str. 8. 
interesa Strateškog projekta jesu trgovina ugroženim vrstama, nedozvoljeni promet otpadom te onečišćenje mora. Kako bi osigurao kontinuirani angažman na području istraživanja i progona kaznenih djela protiv okoliša, Eurojust je u srpnju 2014. godine uspostavio kontaktne točke za kaznena djela protiv okoliša kojima se osigurava vidljiva kontakt-osoba u Eurojustu za praktičare i vanjske interesne grupe i koje će redovito izvještavati Financijski i ekonomski kazneni tim te Kolegij Eurojusta. Uspostava kontaktnih točaka trebala bi podići svijest o podršci koju Eurojust pruža nadležnim nacionalnim tijelima u ovom području te potaknuti razvoj stručnosti i razmjene najbolje prakse među tužiteljima u području kaznenih djela protiv okoliša. ${ }^{21}$ Eurojust ima značajnu ulogu u dijeljenju i prikupljanju najbolje prakse postupanja $i$ to putem koordiniranja nacionalnih akcija, pomoći tužiteljima u državama članicama. Kada državni odvjetnici, koji u pravilu nisu specijalizirani u području zaštite okoliša, pošalju zahtjev za pravnom pomoći svojim kolegama u drugim državama članicama, Eurojust može koordinirati i olakšati pružanje savjeta u pogledu najbolje prakse postupanja. ${ }^{22}$

Jedna od mogućih aktivnosti Eurojusta jest i uspostava zajedničkih istražnih timova (joint investigation teams, skraćeno: JITs). Premda takav oblik pravosudne suradnje u kontekstu kaznenih djela protiv okoliša nije još dostatno razvijen, ovo bi sredstvo suradnje, s obzirom na prednosti JITs-a, posebice omogućavanjem nadležnim tijelima razmjene informacija na brz i jednostavan način, moglo biti od velike pomoći u jačanju pravosudne suradnje. Također, uspostava JITs-a omogućila bi sudjelovanje i doprinos stručnjaka u okviru takvog tima. ${ }^{23}$ Ipak treba uzeti u obzir poteškoće u uspostavi i funkcioniranju zajedničkih istražnih timova a kao rezultat zakonodavnih razlika u državama članicama EU, primjerice u poduzimanju pojedinih procesnih mjera (prikrivenih istražnih radnji i sl.), ali i niz administrativnih barijera. ${ }^{24}$

S obzirom na to da ekološki kriminal često uključuje prekogranični element, u takvim slučajevima može doći do sukoba nadležnosti za vođenje kaznenog postupka. Na temelju članka 12. Odluke Vijeća 2009/948/PUP o sprečavanju i rješavanju sporova o izvršavanju nadležnosti u kaznenim postupcima, Eurojust ima ulogu pružanja pomoći u rješavanju sporova o nadležnosti. ${ }^{25} \mathrm{U}$ skladu s člankom 13., stavkom 7., točkom (a) Odluke o Eurojustu, Eurojust mora biti obaviješten o svakom slučaju spora o nadležnosti do kojeg je došlo ili je vjerojatno da će doći te se predmet u svakom trenutku može uputiti Eurojustu ako barem jedno

21 Ibid., str. 9.

22 Ibid., str. 33.

23 Ibid., str. 34

24 Opš. Block, L.: „EU joint investigation teams: political ambitions and police practices“ u: Hufnagel, S.; Harfield, C.; Bronitt, Simon H. (ed.): Cross-Border Law Enforcement: Regional Law Enforcement Cooperation - European, Australian and Asia-Pacific Perspectives, United Kingdom: Routledge, 2012. str. 102.

25 Kako se navodi u recitalu Odluke o Eurojustu, budući da je Eurojust posebno primjeren za pružanje pomoći u rješavanju sporova o nadležnosti, upućivanje predmeta Eurojustu trebalo bi biti uobičajeni korak kada nije moguće postići konsenzus. 
nadležno tijelo koje je uključeno u izravno savjetovanje to smatra primjerenim. Slučaj pomorske nesreće broda Prestige, koji će detaljnije biti obrađen infra toč. 3.6., jedan je od primjera suradnje država članica i Eurojusta u pogledu rješavanja sukoba nadležnosti. ${ }^{26}$

\subsection{Uloga Europola u kaznenopravnoj zaštiti okoliša}

Europski policijski ured-Europol, osnovan je 1995. Konvencijom o Europolu, ${ }^{27}$ koja je zamijenjena 2009. godine Odlukom Vijeća 2009/371/PUP od 6. travnja 2009. o osnivanju Europskog policijskog ureda (Europol). ${ }^{28}$ Cilj je Europola podupirati i jačati djelovanje nadležnih tijela država članica i njihovu međusobnu suradnju u sprečavanju i suzbijanju organiziranog kriminala, terorizma i drugih oblika teških oblika kriminala koji zahvaćaju dvije ili više država članica. ${ }^{29}$

Europski je parlament 2001. godine prihvatio belgijsku i švedsku inicijativu za donošenje okvirne odluke koja proširuje Europolov mandat na teške oblike međunarodnih kaznenih djela, među ostalim i na kaznena djela protiv okoliša. ${ }^{30}$ Parlament je također pozvao EU da uspostavi zajedničke policijske jedinice za istraživanje, a cilj je bio ojačati učinkovitost suradnje u okviru Konvencije o Europolu, dajući Europolu sredstva za izvršavanje, u posebnim prioritetnim područjima, svoje zadaće vezane uz sve aspekte međunarodnog organiziranog kriminala. U okviru svoje nadležnosti, Europol jača svoju ulogu u borbi protiv organiziranog kriminala te, u određenoj mjeri, i organiziranog ekološkog kriminala. ${ }^{31}$ Tako se tijekom vremena mogu uočiti i promjene te razvoj u načinu postupanja Europola u odnosu na ekološki organizirani kriminal. U počecima je Europol zbog nedostatka informacija u određenoj mjeri odbijao baviti se ovom vrstom kriminala da bi se to s vremenom promijenilo, pogotovo kako je rastao problem organiziranog ekološkog kriminala i prelijevao se u druge države članice. Iako je 2004. godine Europol priznao kako se ne zna mnogo o uključenosti grupa organiziranog kriminala u netradicionalna područja kriminala, istovremeno

26 Case Nr.27/FR/2003. 1995.

Konvencija o osnivanju Europskog policijskog ureda (Konvencija o Europolu) SL C 316, 27. 11.

28 Dalje: Odluka o Europolu. Opš. Klip, A., op. cit. (bilj. 19), str. 436.

29 Temeljne zadaće Europola su, sukladno čl. 5., prikupljanje, pohranjivanje, obrada, analiza i razmjena informacija i obavještajnih podataka; obavješćivanje nadležnih tijela država članica bez odgode preko nacionalnih jedinica o informacijama koje se odnose na njih i o svim utvrđenim vezama između kaznenih djela; pomaganje istraga u državama članicama, posebno prosljeđivanjem svih važnih informacija nacionalnim jedinicama; pozivanje nadležnih tijela predmetnih država članica da pokrenu, vode ili koordiniraju istrage te, u posebnim slučajevima, predlaganje osnivanja zajedničkih istražnih timova.

30 Odluka Vijeća od 6. prosinca 2001. o proširenju ovlasti Europola na bavljenje teškim oblicima međunarodnog kriminala navedenim u Prilogu Konvenciji o Europolu 2001/C 362/01. Lisabonski je ugovor predvidio širu ulogu Europola u borbi protiv prekograničnog kriminaliteta koja može uključiti i „oblike kriminaliteta koji utječu na zajednički interes obuhvaćen politikom Unije“. Pereira, R. M., op. cit. (bilj. 6), str. 139.

31 Fajardo, T.: Organised Crime and Environmental Crime: Analysis of EU Legal Instruments. Study in the framework of the EFFACE research project, Granada: University of Granada, 2015., str. 20. 
je među svoje preporuke u godišnjem izvješću istaknuo potrebu iniciranja situacijskih izvješća u područjima kriminala visokog profita - niskog rizika kao što je ekološki kriminal s naglaskom na uključenost organiziranih grupa. ${ }^{32}$ Europol je u svom izvješću 2013. označio ekološki kriminalitet kao rastuću prijetnju državama članicama Europske unije. Europol je zatim objavio procjenu opasnosti od ekološkog kriminala (Threat Asessment 2013 - Enviromental Crime in the $E U)$ u kojoj je posebno naglašena, kao kaznenopravni fenomen, rastuća opasnost nezakonitog prometa otpadom koji ostaje neprijavljen i neistražen što rezultira identificiranjem vrlo malog broja skupina organiziranog kriminala. ${ }^{33}$

\subsection{Suradnja Eurojusta i Europola s drugim europskim i međunarodnim organizacijama i mrežama u borbi protiv kaznenih djela protiv okoliša}

Na području zaštite okoliša na međunarodnom planu djeluje niz formalnih i neformalnih organizacija i mreža, s kojima tijela Europske unije nastoje usko surađivati s ciljem što učinkovitije borbe protiv ekološkog kriminala.

Mreža Europske unije za provedbu i izvršenje propisa iz područja zaštite okoliša (The European Union Network for the Implementation and Enforcement of Environmental Law, IMPEL) međunarodna je neprofitna udruga čija je svrha podizanje svijesti, izgradnja kapaciteta $\mathrm{i}$ razmjena informacija i iskustava o provedbi, međunarodna suradnja, kao i promicanje europskog zakonodavstva iz područja zaštite okoliša. ${ }^{34} \mathrm{U}$ okviru IMPEL-a provodi se projekt Trans-frontier Shipment of Waste (TFS) Prosecutors' Project koji ima za cilj jačati i dalje razvijati mrežu tužitelja u EU koji se bave progonom kaznenih djela protiv okoliša s posebnim naglaskom na prekogranični prijevoz otpada. U tijeku je izrada baze podataka koja sadrži sudsku praksu vezanu uz prekogranični prijevoz otpada kao i sve druge korisne informacije za progon ovih kaznenih djela. ${ }^{35}$ Posebno se u okviru projekta naglašava uska suradnja s Eurojustom te ENPE-om.

Europska mreža tužitelja za kaznena djela protiv okoliša (European Network of Prosecutors for the Environment, ENPE) neprofitna je udruga osnovana 2012. godine na temelju neformalnog sporazuma tužitelja koji se bave kaznenim

32 Ibid., str. 21.

33 Council of the European Union: EnviCrimeNet - Intelligence Project on Environmental Crime - Preliminary Report on Environmental Crime in Europe, 16438/14, Brussels, 5 December 2014., str. 4. (dalje: IPEC Report) Dostupno na:

https://www.europol.europa.eu/sites/default/files/publications/ipec_report_on_environmental_ crime_in_europe.pdf

34 IMPEL trenutačno okuplja 50 institucija nadležnih za okoliš iz 35 država, uključujući sve države članice EU, Makedoniju, Kosovo, Tursku, Albaniju, Island, Švicarsku i Norvešku. IMPEL je osnovan 1992. godine kao neformalna mreža europskih tijela i ustanova koje se bave provedbom i implementacijom propisa iz područja zaštite okoliša, a 2008. preoblikovan je u međunarodnu udrugu pod belgijskim pravom. Opš. dostupno na mrežnoj stranici IMPEL-a: http://www.impel.eu/

35 Strategic Project on Environmental Crime, Report, str. 34. 
djelima protiv okoliša iz nekoliko država članica EU. ${ }^{36}$ Cilj je ove mreže pomoći praktičarima u povezivanju i dijeljenju iskustava i podataka u vezi s ekološkim kriminalom. U okviru Strateškog projekta o kaznenim djelima protiv okoliša, uspostavljena je uspješna suradnja između Eurojusta te ENPE-a koja bi trebala omogućiti učinkovitiji progon za kaznena djela protiv okoliša, ali i razmjenu znanja i najbolje prakse postupanja s ciljem stvaranja veće zajednice stručnjaka za područje ekološkog kriminala diljem Europe. ${ }^{37} \mathrm{~S}$ jedne strane, Eurojust pruža ENPE-u legitimitet, a s druge strane ENPE pomaže Eurojustu svojim iskustvom i praksom budući da je do sada Eurojust imao vrlo malo iskustava s pravom zaštite okoliša.

Europol je usko povezan uz neformalnu mrežu za borbu protiv ekološkog kriminala EnviCrimNet, koja nastoji povezati policijske službenike i istražitelje kaznenih djela protiv okoliša $s$ ciljem razmjene iskustava i najbolje prakse postupanja. ${ }^{38}$ Europol i EnviCrimNet započeli su u svibnju 2014. godine jednogodišnji Projekt obavještajne službe o kaznenim djelima protiv okoliša (The Intelligence Project on Environmental Crime (IPEC). Cilj je ovog projekta steći uvid i bolje se upoznati s kaznenim djelima protiv okoliša koja utječu na države članice EU, s opsegom takvog kriminala te s poteškoćama u borbi protiv ove vrste kriminala. Projekt je također imao za svrhu utvrditi uključenost skupina organiziranog kriminala te razviti preporuke radi poboljšanja situacije na području EU. ${ }^{39}$

\section{POSEBNOSTI I POTEŠKOĆE U KAZNENOM PROGONU I ISTRAŽIVANJU KAZNENIH DJELA PROTIV OKOLIŠA}

Kao što je uvodno naznačeno, ekološki kriminal svrstava se, s aspekta motivacije za deliktno ponašanje, $\mathrm{u}$ visoko profitno nezakonito djelovanje $\mathrm{s}$ malim stupnjem rizika. Takvoj atribuciji ove vrste kriminala općenito govoreći doprinose neodgovarajući istražni kapaciteti prouzročeni nedostatkom posebno obučenih jedinica tijela kaznenog progona, manjkavostima zakonodavnog okvira prava zaštite okoliša, slabostima i nedostacima u primjeni pravnih propisa, kao i neučinkovitom i blagom kaznenom politikom. ${ }^{40}$

\footnotetext{
36 To su države: Belgija, Finska, Njemačka, Italija, Španjolska, Nizozemska, Švedska i Ujedinjeno Kraljevstvo.

37 Report of the Strategic meeting...., str. 3.

38 Opš. dostupno na: http://www.envicrimenet.com/ Europol stavlja na raspolaganje EnviCrimeNetu svoja dva sustava: Platformu Europola za stručnjake (kao osigurani on-line forum za razmjenu znanja i najboljih praksi) i SIENA Mrežnu aplikaciju za sigurnu razmjenu informacija (za razmjenu operativnih informacija o ekološkom kriminalu). Geysel, F.; Johnson, N.: Priručnik za ekološko umrežavanje, The Regional Environmental Center, 2013., str. 33.

39 IPEC Report, str. 5.

40 Tako Uljanov, S.: „Standardi Interpola u borbi protiv ekološkog kriminala“, u: Ekologija i pravo (ur: Čavoški, A.; Knežević Bojović, A.), Institut za uporedno pravo, Beograd, 2012., str. 71.
} 


\subsection{Organizacijski problemi u kaznenom progonu i istraživanju kaznenih djela protiv okoliša}

Kazneni progon za kaznena djela protiv okoliša rijetko se provodi, ograničen je u svom dosegu te okružen nizom poteškoća. ${ }^{41}$ Učinkovitost kaznenog progona kaznenih djela protiv okoliša ovisi o nizu institucionalnih i organizacijskih čimbenika kao što su ustrojstvo i ovlasti tijela koja sudjeluju u istraživanju i kaznenom progonu, njihova specijalizacija za područje zaštite okoliša, suradnja upravnih i kaznenih tijela, posebice prekogranična suradnja nadležnih tijela, dostupna materijalna sredstva i ljudski resursi za progon ove vrste kriminala.

Poteškoće koje se javljaju u istraživanju i progonu proizlaze ponajprije iz kompleksnog i opsežnog zakonodavstva zaštite okoliša ${ }^{42}$ Budući da kaznena djela protiv okoliša sadrže u pravilu blanketnu dispoziciju, tijela kaznenog progona te sud trebaju poznavati propise iz ovog područja. Stručna terminologija, nedostatak jasnoće i preciznosti, s jedne strane prečeste izmjene zakonodavstva, a s druge strane zastarjelo zakonodavstvo i pravne praznine mogu dovesti do zastoja u otkrivanju i kaznenom progonu kaznenih djela protiv okoliša. Zakonodavstvo iz područja zaštite okoliša zahtijeva posebna znanja, obuku i specijalizaciju tijela kaznenog progona. Slijedom spomenutog, istraživanje ovih kaznenih djela zahtijeva mnogo vremena, pogotovo ako istražitelji i tužitelji nisu specijalizirani upravo za područje zaštite okoliša, a otkrivanje i kažnjavanje počinitelja otežavaju i ograničena materijalna sredstva tijela kaznenog progona koja se u pravilu primarno raspoređuju na istraživanje tradicionalnog kriminaliteta. Visoki su troškovi prikupljanja i pohrane dokaza te provođenja složenih vještačenja i angažiranja stručnjaka. ${ }^{43}$

\subsection{Otkrivanje i prijava kaznenih djela protiv okoliša}

Kaznenim djelima protiv okoliša u pravilu nedostaje neposredna žrtva te ova vrsta kriminala može kroz dulje vrijeme ostati neprimijećena prije nego što eventualna šteta postane vidljiva. ${ }^{44}$ Policija odnosno tijela nadležna za izvršenje zakona obično nisu dovoljno educirana da prepoznaju kada i gdje se javlja ova vrsta kriminala. Ova su tijela opterećena s jedne strane istraživanjem drugih kaznenih djela, a s druge strane nedostatkom poznavanja tehničkog aspekta kaznenih djela protiv okoliša. ${ }^{45}$ Tome treba pridodati i općenito nezainteresiranost za progon i kažnjavanje ovih kaznenih djela koja je primjetna na svim razinama,

${ }^{41}$ Situ, Y.; Emmons, D., op. cit. (bilj. 2)., str. 147.

42 Tako zaštitu okoliša u Republici Hrvatskoj regulira niz zakona te brojni podzakonski akti, pravilnici i uredbe. Neki od zakona iz ovog područja su: Zakon o zaštiti okoliša (NN 80/13, 153/13, 78/15), Zakon o zaštiti zraka (NN 130/11, 47/14), Zakon o održivom gospodarenju otpadom (NN 94/13), Zakon o energiji (NN 120/12, 14/14), Zakon o energetskoj učinkovitosti (NN 127/14).

43 IPEC Report, str. 14

44 Ibid., str. 7.

45 Jaworski, V.: „L'état du droit pénal de l'environnement français: entre forces et faiblesses“, Les Cahiers de droit, vol. 50, n 3-4, 2009., str. 914. 
kod upravnih tijela nadležnih za nadzor i inspekciju, kod tijela kaznenog progona, te naposljetku kod sudaca. ${ }^{46}$

Stopa otkrivenih i prijavljenih kaznenih djela protiv okoliša usko je povezana uz aktivnost upravnih tijela nadležnih za provođenje nadzora u području zaštite okoliša. Inspekcije ministarstva nadležnog za zaštitu okoliša u pravilu bi trebale prve primijetiti i prijaviti kaznena djela protiv okoliša. Inspekcijski nadzori koje provode od ključne su važnosti za otkrivanje povreda propisa o zaštiti okoliša, a time i do takvih povreda koje predstavljaju kaznena djela protiv okoliša. Međutim, mogućnosti i angažman ovih tijela u pogledu prijave kaznenih djela protiv okoliša ovisi o nizu čimbenika, o dostupnim sredstvima, postavljenim prioritetima te o samom zakonodavstvu. ${ }^{47}$

\subsection{Tijela nadležna za istraživanje i progon kaznenih djela protiv okoliša}

Uspjeh državnog odvjetnika kao ovlaštenog tužitelja u progonu kaznenih djela protiv okoliša ovisi o stručnim znanjima eksperata, vještačenjima, sredstvima koja ima na raspolaganju, suradnji s regulatornim agencijama, tijelima nadležnih ministarstava. Istraživanje onečišćenja okoliša u određenoj sastavnici okoliša, u zraku, vodi ili tlu, zahtijeva specijalizirana znanja iz različitih područja prirodnih znanosti, geologije, kemije, postupanja s opasnim i otrovnim tvarima, te istražitelji trebaju biti u stanju protumačiti rezultate znanstvenih testova. ${ }^{48}$ Stoga je od posebne važnosti timski pristup te interdisciplinarnost $u$ istraživanju kaznenih djela protiv okoliša, te je jednako važan terenski rad kao i laboratorijski rad. ${ }^{49}$

U većini država članica EU za istraživanje kaznenih djela protiv okoliša nadležni su policija, uredi državnih odvjetnika, a ponegdje i specijalizirane policijske agencije za gospodarski kriminal te, kada se radi o kriminalitetu povezanom uz ugrožene prirodne vrste, carinske agencije. ${ }^{50} \mathrm{U}$ gotovo svim državama članicama postoje i različite administrativne agencije i inspektorati kao nadzorna tijela. Jedan broj država uspostavio je specijalizirane jedinice za ekološki kriminal bilo na regionalnoj ili na nacionalnoj razini. ${ }^{51}$ Neke države kao što su Norveška, Španjolska, Nizozemska, imaju specijalizirane odjele tužitelja za kaznena djela protiv okoliša koji su nadležni za progon težih kaznenih djela

46 Ibid.

47 IPEC Report, str. 10.

48 Primjerice, da bi se otkrio izvor onečišćenja tla određenom otrovnom kemikalijom potrebno je poznavati kako kemikalije s različitim svojstvima prolaze kroz tlo, kakav je sastav tla i koje su geološke karakteristike određenog područja. Lynch, M. J.; Burns, R. G:, Stretesky, P. B.: Environmental Law, Crime, and Justice, Second edition, LFB Scholarly Publishing, 2014., str. 220.

49 Ibid., str. 209.

50 IPEC Report, str. 9.

51 Nekoliko država je oformilo Nacionalni operativni tim za suzbijanje djela protiv okoliša (NEST) sukladno preporuci Interpola, neki rade u grupama ili slično, kako bi unaprijedili suradnju na nacionalnoj razini. Ibid. 
protiv okoliša. ${ }^{52}$ Međutim, velik je broj država kod kojih je očigledan nedostatak iskusnog osoblja odnosno institucijskog iskustva. Također, u velikom broju slučajeva nije na centralnoj razini uspostavljena jedinica za prikupljanje i analizu podataka o kaznenim djelima protiv okoliša. ${ }^{53}$

Države članice EU u anketi provedenoj u okviru projekta IPEC istaknule su određene probleme vezane uz suradnju upravnih i kaznenih tijela oko istraživanja kaznenih djela protiv okoliša. Razmjena informacija je u pravilu spora i nepotpuna. Tijela kaznenog progona u pravilu nemaju pristup bazama podataka regulatornih agencija koje imaju drugačije zadaće i ciljeve od policije, a ponekad i različite interese. Također se ističe kako regulatornim tijelima nedostaje dovoljno kapaciteta za vršenje nadzora i inspekcija. Jedan od organizacijskih izazova u borbi protiv ekološkog kriminala proizlazi iz situacija u kojima postojeće specijalizirane agencije za zaštitu okoliša imaju potrebna tehnička znanja i stručnjake ali nemaju istražne ovlasti u odnosu na kaznena djela protiv okoliša, a s druge strane redovnim tijelima kaznenog progona, koja imaju istražne ovlasti, nedostaje specijaliziranih znanja. ${ }^{54}$

Čak i kada postoje specijalizirani tužitelji za kaznena djela protiv okoliša, može doći do poteškoća tijekom suđenja budući da kaznene postupke za ova kaznena djela vode suci koji nemaju takvih znanja i iskustava što se onda odražava i na izrečenim sankcijama. ${ }^{55}$ Osim što ne postoje specijalizirana znanja iz područja zaštite okoliša, sudovi slabo poznaju zakonodavstvo Europske unije.

\subsection{Prekogranična suradnja}

Jedna od prepreka u učinkovitoj borbi protiv ekološkog kriminala jest nedostatak međunarodnog pristupa $u$ istraživanju i progonu kaznenih djela protiv okoliša. Kaznena djela protiv okoliša sve češće uključuju prekogranični element tako da porast međunarodne trgovine te ukidanje graničnih kontrola u šengenskom prostoru pridonose povećanju ove vrste kriminaliteta.${ }^{56}$ Prekogranični element se kod ovih kaznenih djela može očitovati na više načina: u odnosu na učinak koje

52 U Španjolskoj je oformljen nacionalni odjel za kaznena djela protiv okoliša koji se sastoji od policijskih istražitelja, četiriju tužitelja i od stručnjaka iz različitih područja. Osim toga, u svim je regijama ustrojena široka mreža tužitelja specijaliziranih za kaznena djela protiv okoliša. Nacionalni odjel daje savjete lokalnoj policiji i tužiteljima koji se bave lakšim kaznenim djelima protiv okoliša. U Nizozemskoj su u četiri grada ustrojeni posebni uredi javnog tužitelja za prijevare i ekološki kriminal, a postoje i posebne policijske jedinice koje se bave istraživanjem kaznenih djela protiv okoliša. U Norveškoj je osnovano nacionalno tijelo za istraživanje i progon gospodarskog i ekološkog kriminala, nadležno za istraživanje i progon težih kaznenih djela protiv okoliša. Svaki policijski distrikt ima specijalizirane policijske službenike i tužitelje za istraživanje ekološkog kriminala, a nekoliko zakona u norveškom zakonodavstvu regulira problematiku kaznenih djela protiv okoliša. Strategic Project on Environmental Crime, Report, str. 25-28. Dostupno na: http://www.eurojust.europa.eu/doclibrary/Eurojust-framework/ Pages/casework.aspx

53 IPEC Report, str. 10.

54 Strategic Project on Environmental Crime, Report, str. 31.

55 Ibid.

56 Ibid., str. 5. 
pojedine nezakonite radnje imaju kao na primjer kod onečišćenja mora ili zraka koje obuhvati područje više država, zatim u odnosu na cilj koji se takvim djelima postiže, primjerice kod nezakonitog prometa opasnog otpada u zemlje Trećega svijeta. Osim toga, počinitelj odnosno članovi grupa organiziranog kriminala mogu svoje nezakonite aktivnosti poduzimati na području više država. ${ }^{57}$

Pribavljanje informacija o istragama koje su u tijeku može biti teško, pogotovo kada ne postoji volja za suradnjom, a poteškoće se javljaju u prikupljanju i osiguranja dokaza u predmetima s prekograničnim elementom. Kao jedna od glavnih prepreka ističe se nedostatak uhodanog komunikacijskog sustava te mreže kontaktnih točaka za razmjenu podataka i informacija između različitih nadležnih tijela. Većina suradnje odvija se neformalno. Razmjenu podataka i suradnju često sprečavaju propisi o zaštiti podataka. U slučajevima kada i dolazi do službene razmjene podataka i suradnje, ona je vrlo spora i birokratična, u suprotnosti s vrlo dinamičnim kriminalnim mrežama kojima se suprotstavlja. Za sada nema zajedničkih istraga koje bi se usredotočile na ekološki kriminal. ${ }^{58}$ Policijska i pravosudna suradnja ne bi smjele biti ograničene samo na razmjenu najbolje prakse već bi trebala uključiti zajedničke treninge, izgradnju zajedničke tehničke infrastrukture za suradnju radi brže razmjene informacija. ${ }^{59}$ Stoga je u ovom kontekstu posebno značajna aktivnost tijela Europske unije o kojima je bilo riječi u prethodnom poglavlju.

Dijelom problem stvara i različito i neusklađeno zakonodavstvo država članica EU te različitost u primjeni postojećih EU-direktiva. Neusklađenost u pogledu visine i vrste sankcija za kaznena djela protiv okoliša može dovesti u pitanje primjenu pojedinih instrumenata pravosudne suradnje koji se odnose i na ovu vrstu kaznenih djela, kao što su Europski uhidbeni nalog te Europski nalog za pribavljanje dokaza. ${ }^{60}$ Tako je primjerice izdavanje europskog uhidbenog naloga moguće za kaznena djela za koja je predviđena kazna zatvora u najdužem trajanju od jedne godine zatvora ili više pa ako neka država članica ima propisane blaže sankcije neće biti moguće izvršiti EUN. Za kaznena djela protiv okoliša, izdavanje europskog uhidbenog naloga bez provjeravanja dvostruke kažnjivosti moguće je samo ako je za ta djela državi izdavanja propisana kazna zatvora ili mjera koja uključuje oduzimanje slobode u najdužem trajanju od tri godine ili više.

57 Spapens, T.: „Cross-Border Police Cooperation in Tackling Environmental Crime“, u: Gerardu, J. et al. (ed): Ninth International Conference on Environmental Compliance and Enforcement 2011., INECE 2011., str. 237.

58 IPEC Report, str. 15-16.

59 Spapens, T., op. cit. (bilj. 57), str. 247.

60 Pereira, R.: „Legal basis for harmonisation of environmental criminal law int he EU: past and future challanges“, u: Andenæs, M.; Andersen, C. B. (eds): Theory and Practice of Harmonisation, Cheltenham, UK: Edward Elgar, 2011., str. 417. 


\subsection{Dokazivanje kaznenih djela protiv okoliša}

Osim organizacijskih poteškoća koje otežavaju otkrivanje kaznenih djela protiv okoliša, do poteškoća dolazi i u dokazivanju počinjenja ovih kaznenih djela te krivnje počinitelja. Uspješnost kaznenog progona za kaznena djela protiv okoliša ovisi o dokaznim radnjama koje sukladno normama kaznenog procesnog zakonodavstva stoje na raspolaganju u postupcima za ova kaznena djela. Visina zapriječenih sankcija obično ne svrstava kaznena djela protiv okoliša u katalog djela za koje su dopuštene složene istražne radnje kao što su mjere presretanja komunikacije.

Za utvrđivanje počinjenja djela i krivnje počinitelja u pravilu će neophodno biti provođenje različitih vještačenja. Od ključne je važnosti provođenje vještačenja u što ranijim stadijima kaznenog postupanja, jer onečišćivači često mogu pod utjecajem izvanjskih čimbenika i vremenskih prilika vrlo brzo iščeznuti te može doći do smanjenja koncentracije onečišćenja, a time se može dovesti u pitanje i postojanje samog kaznenog djela. ${ }^{61} \mathrm{U}$ tom pogledu, u postupcima za kaznena djela protiv okoliša posebno je izazovno pitanje čuvanja i osiguranja dokaza, s obzirom na prirodu kaznenih djela protiv okoliša, ali i s obzirom na nedostatak tehničkog, stručnog iskustva te na ograničena materijalna sredstva. ${ }^{62}$ Dokazi kaznenih djela protiv okoliša zahtijevaju najveću pažnju u odnosu na korištenje prikladnih znanstvenih protokola za prikupljanje podataka te je potrebno poduzeti korake radi osiguranja da uzorci ne budu kontaminirani. Analiza takvih uzoraka može zahtijevati korištenje opreme i znanstvenih tehnika koje su veoma skupe. Posebno treba voditi računa o prikupljanju i čuvanju kemijskih dokaza koji mogu biti opasni ili toksični ili koji imaju potencijal reagirati s drugim kemikalijama ili tvarima. ${ }^{63}$

Kod ovih kaznenih djela mogu nastati poteškoće u utvrđivanju visine materijalne štete i procjeni financijske dobiti postignute kaznenim djelom kao i u uspostavljanju veze između nastale materijalne štete i kaznenog djela, a povezano također uz nedostatne zakonodavne kriterije i pravne praznine. U slučajevima kada je stjecanje imovinske koristi temeljni motiv počinjenja ovih kaznenih djela, u kojima postoji sumnja u uključenost skupina organiziranog kriminala, neophodno je $u$ što ranijim fazama kaznenog postupanja odrediti mjere osiguranja oduzimanja imovinske koristi. ${ }^{64}$

61 Malis Sazdovska, M.: „Usage of Special Investigation Measures in Detecting Environmental Crime: International and Macedonian Perspective“, u: Mesko, G.; Dimitrijević, D., Fields, C. B. (Eds.): Understanding and Managing Threats to the Environment in South Eastern Europe, Springer, 2011., str. 131.

62 Lynch, M. J.; Burns, R. G:, Stretesky, P. B., op. cit. (bilj. 48), str. 210.

63 Ibid.

${ }^{64}$ Inozemna iskustva (Engleska) ukazuju na izazove u pogledu dokazivanja kaznenih djela povezanih uz promet otpadom. Za ova kaznena djela koristi se niz istražnih tehnika kao što su nadzor komunikacije, oduzimanje dokumentacije i sl. te obrana okrivljenika učestalo iznosi prigovore u pogledu legitimiteta provođenja istrage, pogotovo u odnosu na doseg ovlasti istražnih tijela i način na koji se spomenute istražne radnje provode. „Interview with Anne Brosnan, UK Environment Agency“, EUROJUST News, Issue No. 10, December 2013, str. 8. Engleski su tužitelji od 2011. godine osigirali pred sudovima naloge 


\subsection{Slučaj Prestige - onečišćenje okoliša s međunarodnim elementom}

Pomorska nesreća tankera Prestige 2002. godine ${ }^{65}$ primjer je slučaja velikog onečišćenja okoliša s prekograničnom dimenzijom koji je ukazao na sve poteškoće u provođenju kaznenog postupka za kaznena djela protiv okoliša te je rezultirao usvajanjem posebnih zakonodavnih mjera u okviru EU. ${ }^{66}$

\section{a. Nadležnosti za kazneni progon}

Izlijevanje nafte s potopljenog tankera Prestige prouzročilo je veliku štetu morskom okolišu Francuske i Španjolske, ali i Portugala. Budući da su i Francuska i Španjolska tvrdile da su pretrpjele veliku štetu s aspekta kaznenopravne i građanskopravne odgovornosti, te da su obje države bile voljne preuzeti kazneni progon, otvorilo se pitanje koja će od dvije obalne države čije su morske vode onečišćene biti nadležna za kazneni progon počinitelja koji je plovio pod zastavom treće države. ${ }^{67} \mathrm{Uz}$ suglasnost nadležnih tijela uključenih država, u rješavanje sukoba nadležnosti uključio se Eurojust koji je organizirao prvi sastanak između nadležnih tijela Španjolske, Francuske i Portugala s ciljem razmjene informacija među državama članicama. Zaključeno je da bi jedno suđenje osiguralo učinkovitije kažnjavanje i u većoj mjeri zaštitilo interese žrtava te da je, s obzirom na sve okolnosti slučaja, Španjolska u najboljem položaju voditi kazneni postupak. ${ }^{68}$ Odluka Eurojusta je pri vaganju španjolskih i francuskih interesa u ovom slučaju pragmatski uzela u obzir postupovne čimbenike. Naglasak je bio na svrhovitosti vođenja kaznenog postupka u odnosu na mjesto na kojem se nalazila većina dokaza i svjedoka. ${ }^{69}$ Glavni državni odvjetnik Španjolske prihvatio je preporuku

o konfiskaciji imovine u vrijednosti 3533937 GBP. „Interview with Jonathan Robinson“, EUROJUST News, Issue No. 10, December 2013, str. 7.

65 Dvadeset i šest godina star tanker Prestige, ploveći pod bahamskom zastavom uz španjolsku obalu, doživio je 13. studenog 2002. godine pomorsku nesreću koja je trajala šest dana da bi se na koncu 19. studenog brod prepolovio i potopio što je dovelo do izlijevanja gotovo 70 tona guste nafte u Atlantski ocean. Naftna mrlja onečistila je tisuće kilometara španjolske obale te se proširila i na portugalsku te francusku obalu. U to vrijeme brodom je zapovijedao kapetan Apostolos Mangouras, grčki državljanin koji je u trenutku nesreće od španjolskih vlasti zatražio mjesto utočišta kako bi spasio brod i spriječio izlijevanje nafte no španjolske su vlasti donijele odluku o udaljavanju broda od španjolske obale. Ovo izlijevanje nafte bilo je najveća ekološka katastrofa u povijesti te države. „The Prestige case“, EUROJUST News, Issue No. 10, December 2013, str. 14.

66 U okviru mjera donesenih nakon nezgode tankera Prestige 2005. usvojena je Direktiva o onečišćenju mora s brodova koja obvezuje države članice na uvođenje sankcija (kaznenih i prekršajnih) za povredu MARPOL pravila iz Priloga I. i II. o onečišćenju mora s brodova uljem i štetnim tvarima. Ćorić, D.: „Direktiva EU o onečišćenju mora s brodova i nadležnosti obalnih država“, Zbornik Pravnog fakulteta Sveučilišta u Rijeci, sv. 32, br. 2, 2011., str. 858.

67 Pozdnakova, A.: Criminal Jurisdiction over Perpetrators of Ship-Source Pollution: International Law, State Practice and EU Harmonisation, Martinus Nijhoff Publishers, 2012., str. 156-157.

68 Ibid., str. 156-157.

${ }_{69} \mathrm{~S}$ obzirom na izravan kontakt između španjolskih vlasti te broda i posade od samog trenutka nesreće, više je dokaza prikupljeno u Španjolskoj te se više oštećenika nalazilo u toj državi s tim da su se neki oštećenici iz Francuske prethodno pridružili postupku u Španjolskoj. U svjetlu svega navedenog, država zastave broda (Bahami) nije bila primjerena kao država nadležna za vođenje postupka u ovom slučaju. Ibid., str. 157. 
Dr. sc. Marija Pleić: Kazneni progon i istraživanje kaznenih djela protiv okoliša Zbornik radova Pravnog fakulteta u Splitu, god. 53, 2/2016., str. 601.-622.

Eurojusta u pogledu nadležnosti za kazneni progon te je prihvatio poduzeti sve potrebne mjere s ciljem zaštite španjolskih i francuskih žrtava. Rezultat ove suradnje bio je to da su francuski oštećenici imali jednak položaj kao i španjolski te je francuski državni odvjetnik sudjelovao u raspravi kada su se ispitivali neki francuski oštećenici. ${ }^{70}$

\section{b. Pritvor i jamstvo}

Slučaj Prestige otvorio je i neka druga kaznenoprocesna pitanja, a koja su bila predmetom odlučivanja Europskog suda za ljudska prava (dalje: ESLJP) povodom zahtjeva podnositelja zahtjeva kapetana Mangourasa o navodnoj povredi čl. 5., st. 3. Europske konvencije za zaštitu ljudskih prava i temeljnih sloboda (dalje: EKLJP), a vezano uz pravo na puštanje na slobodu uz jamčevinu). ${ }^{71}$ Nakon otvaranja istrage, kapetan tankera Prestige A. Mangouras zadržan je u pritvoru uz mogućnost puštanja na slobodu uz jamčevinu od tri milijuna eura. Ovakva odluka obrazložena je ozbiljnošću i težinom kaznenih djela koja su mu se stavljala na teret (uzrokovanje štete na prirodnim resursima i okolišu i nepostupanje sukladno uputama upravnih tijela) i činjenicom da se radi o stranom državljaninu koji ni na koji način nije vezan sa Španjolskom. Utvrđena jamčevina premašivala je iznos koji je podnositelj zahtjeva mogao platiti s obzirom na svoje osobne prilike, no domaći su sudovi kod određivanja visine jamčevine uzeli u obzir i težinu kaznenog djela koje mu se stavlja na teret kao i „profesionalni ambijent“ podnositelja zahtjeva. ${ }^{72}$ ESLJP je stoga, povodom zahtjeva podnositelja, trebao utvrditi je li takav pristup u određivanju visine jamčevine u skladu s člankom 5., st. 3. EKLJP-a. Primjenjujući opća načela utvrđena u svojoj praksi na konkretan slučaj, ESLJP je naglasio kako kod tumačenja zahtjeva iz članka 5., st. 3. ne smije zanemariti rastuću i legitimnu zabrinutost, kako u Europi tako i na međunarodnom planu, u odnosu na prijestupe i kaznena djela iz područja ekologije, kao i tendenciju da se kazneno pravo upotrijebi kao sredstvo za nametanje obveza ekološke zaštite uvedenih instrumentima europskog i međunarodnog prava. ${ }^{73}$ ESLJP je ustvrdio

70 Pitanje položaja francuskih oštećenika bilo je najosjetljivije pitanje u prihvaćanju predmeta te je za francuske vlasti bilo najvažnije osigurati da francuski državljani budu zaštićeni. „The Prestige case“, EUROJUST News, Issue No. 10, December 2013, str. 14. Sukladno španjolskom kaznenom procesnom zakonodavstvu, uz državnog odvjetnika se na strani tužitelja mogu pojaviti i privatne osobe te se može odlučiti u kaznenom postupku o njihovom imovinskopravnom zahtjevu. Ovom kaznenom postupku priključili su se u tom svojstvu, među ostalim, španjolska i francuska vlada, regije, pokrajine, gradovi i općine pogođeni izlijevanjem ulja, nevladine organizacije za zaštitu okoliša, tvrtke vezane uz ribarstvo i turizam. Ovi su subjekti tražili odštetu u iznosu od 2,2 milijarde eura. Međutim, budući da naposljetku nije dokazana krivnja optuženika za nesreću, nije dosuđena ni naknada štete. De Buerba, A.; Uria, A.: Prestige case: €2.2 billion in environmental damages at stake, 9. 6. 2014., http://www. internationallawoffice.com/Newsletters/White-Collar-Crime/Spain/Prez-Llorca/Prestige-case-22-billionin-environmental-damages-at-stake

71 Mangouras protiv Španjolske, zahtjev br. 12050/04, presuda od 28. 9. 2010. [GC] U presudi od 8. siječnja 2009. Vijeće Suda jednoglasno je utvrdilo da nije došlo do povrede članka 5., st. 3. Konvencije.

72 Podnositelj zahtjeva bio je lišen slobode 83 dana da bi potom bio oslobođen nakon što je položena bankarska garancija na tri milijuna eura.

${ }^{73}$ Mangouras protiv Španjolske, $\$ 86$. S obzirom na posebne okolnosti slučaja podnositelja zahtjeva i ogromnu ekološku štetu izazvanu zagađenjem mora, u razmjerima koji se rijetko viđaju, nije iznenađujuće 
kako sama činjenica da je isplatu iznosa jamčevine izvršilo osiguravajuće društvo kod kojega je brodovlasnik osiguran potvrđuje da su španjolski sudovi, pozivajući se na ,profesionalno okruženje“" podnositelja zahtjeva, ispravno zaključili, makar i implicitno, da postoji odnos između podnositelja zahtjeva i osoba koje trebaju osigurati bankarsku garanciju. ${ }^{74}$ Stoga je Sud zaključio da su španjolske vlasti, s obzirom na poseban kontekst ovog slučaja i na katastrofalne ekološke i ekonomske posljedice, imale pravo kada su uzele u obzir težinu djela koje se podnositelju zahtjeva stavlja na teret i obujam štete koja mu se pripisuje da ju je počinio pa da nije došlo do povrede čl. 5., st. 3. EKLJP-a. ${ }^{75}$

\section{c. Presuda}

Nakon dugotrajne istrage, na optuženičkoj su se klupi u slučaju Prestige našli kapetan broda, glavni strojar broda te tadašnji ravnatelj španjolske trgovačke mornarice, a drugi časnik broda kao četvrti optuženik bio je u bijegu. Suđenje je započelo 16. 10. 2012., a završilo je 10. 7. 2013. godine. Visoki galicijski sud u La Coruni donio je 13. 11. 2013. oslobađajuću presudu za trojicu optuženika u odnosu na kazneno djelo nanošenja štete okolišu i prirodnim prostorima pod zaštitom, a grčkog kapetana osudio je na devet mjeseci zatvora zbog ozbiljnog neposluha vlastima budući da je u početku odbio otegliti brod na pučinu kako su to zatražile španjolske vlasti. Sud je ustvrdio da tanker Prestige, iako je posjedovao odgovarajuće certifikate i dokumente za plovidbu, nije bio pravilno održavan. Međutim, u postupku nije dokazano da su kapetan, upravitelj stroja te prvi časnik bili svjesni stvarnih uvjeta plovila, dakle da u odnosu na prouzrokovanje nesreće nije postajala ni namjera ni nehaj. Činjenica da je kapetan broda osuđen za nepoštovanje vlasti ne znači da je odgovoran za štetu prouzročenu izlijevanjem nafte. $^{76}$

\section{KAZNENI PROGON KAZNENIH DJELA PROTIV OKOLIŠA U REPUBLICI HRVATSKOJ}

Kaznenopravna zaštita okoliša u Republici Hrvatskoj, kao i u susjednima, relativno je novi oblik pravne zaštite okoliša. Sve opće značajke borbe protiv kaznenih djela protiv okoliša navedene u prethodnim poglavljima načelno vrijede i za Republiku Hrvatsku. Međutim, kod nas posebno dolazi do izražaja vrlo niska svijest o opasnosti ove vrste kriminala što se odražava u gotovo beznačajnom udjelu ovih kaznenih djela u ukupnom kriminalitetu. Premda Kazneni zakon polazi od ekocentričnog modela koji pruža neposredni i najviši sustav zaštite

\footnotetext{
to što su sudske vlasti prilagodile traženi iznos jamčevine razmjerima nanesene štete, kako bi osigurale da odgovorne osobe ne izbjegnu pravdi i da na taj način ostanu bez položene bankarske garancije.

74 Ibid., $§ 90$.

75 Ibid., § 92-93.

76 De Buerba, A.; Uria, A., op. cit. (bilj. 70).
} 
okoliša, ${ }^{77}$ takav zakonodavčev pristup ne odražava se još uvijek u svijesti i u aktivnostima nadležnih upravnih tijela te tijela kaznenog progona, pa shodno tome ni u kažnjavanju počinitelja za ova kaznena djela.

\subsection{Otkrivanje i prijava kaznenih djela protiv okoliša}

Kaznena djela protiv okoliša, propisana u glavi XX. Kaznenog zakona, spadaju u kategoriju kaznenih djela za koja se progon vrši po službenoj dužnosti. Ovlašteni je tužitelj državni odvjetnik koji progon pokreće po službenoj dužnosti u javnom interesu. Sukladno čl. 204., st. 1. Zakona o kaznenom postupku, ${ }^{78}$ svatko je dužan prijaviti kazneno djelo za koje se postupak pokreće po službenoj dužnosti, koje mu je dojavljeno ili za koje je saznao.

Zakon o zaštiti okoliša ${ }^{79}$ predviđa obvezu nadležnih upravnih tijela na podnošenje kaznene prijave kada se inspekcijskim nadzorom utvrdi da je počinjeno kazneno djelo. Prema članku 258. Zakona o zaštiti okoliša, u slučaju kada se inspekcijskim nadzorom utvrdi da je povrijeđen Zakon o zaštiti okoliša i/ ili propis donesen na temelju ovoga Zakona, Ministarstvo treba podnijeti optužni prijedlog prema Prekršajnom zakonu ako se radi o prekršaju, odnosno podnijeti kaznenu prijavu nadležnom tijelu zbog kaznenog dijela te poduzeti i druge mjere i izvršiti druge radnje koje je ovlašteno poduzeti i izvršiti na temelju Zakona i posebnog propisa. Istu obvezu imaju, prema članku 258.a, inspekcijske službe nadležne za obavljanje nadzora u području okoliša ako se u koordiniranom inspekcijskom nadzoru utvrdi da je povrijeđen Zakon i/ili propis donesen na temelju ovoga Zakona u dijelu koji se odnosi na pojedinu sastavnicu okoliša i zaštitu od utjecaja na okoliš. Za progon kaznenih djela protiv okoliša od iznimne je važnosti podnošenje detaljnih i kvalitetnih kaznenih prijava, uz navođenje svih dokaza koja su nadležnim upravnim tijelima dostupna kao i poduzimanje potrebnih radnji da bi se sačuvali tragovi kaznenog djela te drugi dokazi, a sukladno čl. 204. ZKP-a. U Republici Hrvatskoj ne postoje specijalizirane policijske jedinice koje bi se bavile ekološkim kriminalom niti u okviru državnog odvjetništva postoji poseban odjel za ekološki kriminalitet kao što je to oformljeno u nekim državama članicama EU.

\subsection{Kazneni progon}

Budući da je za većinu kaznenih djela iz glave XX. Kaznenog zakona propisana kazna zatvora do pet godina, za kaznena djela protiv okoliša u pravilu će se voditi kazneni postupak s jednostavnijim procesnim formama. ${ }^{80}$ To znači da se za ova

77 V. Turković i dr.: Komentar Kaznenog zakona i drugi izvori novoga hrvatskog kaznenog zakonodavstva, Zagreb, 2013., str. 263.

78 Zakon o kaznenom postupku, Narodne novine br. 152/08, 76/09, 80/11, 121/11, 91/12, 143/12, $56 / 13,145 / 13,152 / 2014$.

79 Zakon o zaštiti okoliša, Narodne novine br. 80/2013, 153/2013, 78/2015.

80 Najstrože su sankcije propisane za teška kaznena djela protiv okoliša iz čl. 214. Kaznenog zakona. 
kaznena djela ne provodi istraga već državni odvjetnik može naložiti istražitelju provođenje dokaznih radnji ili pak sam provesti dokazne radnje koje su svrhovite za podizanje optužnice. Istragu je, kao poseban stadij kaznenog postupka, moguće provesti za kazneno djelo onečišćenja okoliša, čl. 193., st. 2. Kaznenog zakona, kada je došlo do ugrožavanja života ili zdravlja ljudi te za oblike teških kaznenih djela protiv okoliša propisane čl. 214., st. 1. i 2. i 5. Kaznenog zakona. ${ }^{81} \mathrm{Ni}$ za jedno od ovih kaznenih djela istraga nije obligatorna te državni odvjetnik može, sukladno čl. 341., st. 3. ZKP-a, podići neposrednu optužnicu.

Za kaznena djela iz ove glave Kaznenog zakona nije moguće provođenje posebnih dokaznih radnji iz čl. 332. ZKP-a, koje obuhvaćaju, inter alia, nadzor i tehničko snimanje razgovora i drugih komunikacija na daljinu, presretanje, prikupljanje i snimanje računalnih podataka itd., osim ako ova kaznena djela ne bi bila počinjena u sastavu zločinačkog udruženja.

Kod kaznenih djela protiv okoliša u pravilu će biti neophodno izvesti dokaz vještačenjem, odnosno zatražiti nalaz i mišljenje vještaka odgovarajuće struke kako bi se uopće utvrdilo postojanje kaznenog djela a potom i krivnja okrivljenika. Zakonski opis kaznenih djela protiv okoliša sadrži pojmove koje je potrebno protumačiti uz pomoć vještaka različitih struka, primjerice rudarstva, geologije, šumarstva, ovisno o kojem se kaznenom djelu radi odnosno koja je sastavnica okoliša ugrožena. Tako je kod kaznenog djela opustošenja šume potrebno saslušanjem vještaka šumarske struke točno utvrditi je li okrivljenik sječom šume ovu opustošio i time ostvario objektivna obilježja inkriminiranog kaznenog djela. ${ }^{82}$ Osim vještaka, tijekom postupka tijelo koje vodi postupak može angažirati stručnjake i na drugi način, odnosno kao stručna pomoć prilikom poduzimanja pojedinih dokaznih radnji. ZKP tako razlikuje stručne osobe, stručne pomoćnike, stručne suradnike. ${ }^{83}$

Kada je riječ o dokazivanju krivnje, okrivljenik će u pravilu koristiti prigovor da nije bio svjestan protupravnosti radnje koju je poduzeo. Kaznena djela protiv okoliša u pravilu su kaznena djela ugrožavanja, za postojanje kaznenog djela nije potrebno da dođe do povređivanja zaštićenog pravnog dobra odnosno okoliša. Tužitelj treba dokazati da je radnja dovela do ugrožavanja okoliša te krivnju počinitelja. Za ova kaznena djela predviđeno je kažnjavanje za nehaj, s obzirom na to da će se najčešće i raditi o počinjenju djela s ovim oblikom krivnje, ${ }^{84}$ što olakšava dokazivanje. Međutim, s druge strane, budući da su kaznena djela protiv

81 Ako je kaznenim djelom iz članka 193., stavka 1. i 2., članka 194., stavka 1. i 2., članka 196., stavka 1. i 2., članka 197., stavka 1., članka 198., stavka 1. i članka 199. ovoga Zakona prouzročena teška tjelesna ozljeda jedne ili više osoba, ili se promjene prouzročene onečišćenjem ne mogu dulje vrijeme otkloniti, ili nastupi velika nesreća, ako je kaznenim djelima navedenima u stavku 1. ovoga članka prouzročena smrt jedne ili više osoba, ako je kaznenim djelom iz članka 200., stavka 1. i 2., članka 201., stavka 1., 2. i 3 . i članka 202., stavka 1. i 2. ovoga Zakona prouzročena znatna šteta.

82 Rješenje Županijskog suda u Koprivnici, II Kž 76/2008-2 od 6. 3. 2008., dostupno na www. iusinfo.hr

83 V. Krapac, D.: Kazneno procesno pravo, Prva knjiga, Institucije, VI. izmijenjeno i dopunjeno izdanje, Zagreb, 2014., str. 501.

${ }^{84}$ Kazneni zakon RH za većinu kaznenih djela protiv okoliša predviđa kažnjavanje nehaja. 
okoliša u pravilu kaznena djela s blanketnom dispozicijom, okrivljenik će se pozivati na neotklonjivu zabludu o protupravnosti kao razlog isključenja krivnje koja dovodi do oslobađajuće presude. ${ }^{85}$

\subsection{Statistički pregled}

U ukupnoj strukturi kriminala u Republici Hrvatskoj kaznena djela protiv okoliša zastupljena su na godišnjoj razini u relativno beznačajnom postotku. Prema Izvješću Državnog odvjetništva Republike Hrvatske za 2013. godinu, kaznena djela protiv okoliša u strukturi kriminaliteta odraslih osoba (osobe od navršene 21 godine) obuhvaćala su tek 1,2\% (aps. 352), a u strukturi kriminaliteta pravnih osoba 2,3\% (aps. 16) ukupnog kriminaliteta u 2013. godini. U 2013. bilo je ukupno 186 kaznenih prijava $(0,5 \%)$ protiv nepoznatog počinitelja od čega je u 16 slučajeva $(8,6 \%)$ počinitelj otkriven. ${ }^{86} \mathrm{U}$ 2014. godini došlo je do pada broja prijavljenih osoba za kaznena djela iz glave XX. u odnosu na prethodnu godinu (236), te su u ukupnoj strukturi kriminaliteta participirali sa $0,9 \%$. Od toga, najzastupljenije je kazneno djelo ubijanja i mučenja životinja te protuzakonitog lova i ribolova. Broj prijavljenih pravnih osoba za kaznena djela protiv okoliša u 2014. iznosio je 19 (2,1 \%). Radi se o prijavama za kazneno djelo protupravne eksploatacije rudnog blaga iz čl. 211. KZ-a (11 prijavljenih) i protupravne gradnje iz čl. 212. KZ-a (5 prijavljenih). Prvi put su prijavljene dvije pravne osobe za kazneno djelo onečišćenja okoliša iz čl. 193. KZ-a i jedna pravna osoba zbog kaznenog djela pustošenja šuma iz čl. 209. KZ-a.

U Izvješću DORH-a naglašava se kako u ovoj glavi ima kaznenih djela za koja nikada nije podnijeta kaznena prijava, jednim dijelom zato što se takva kaznena djela još ne čine kod nas, a jednim dijelom zato što je ekološka svijest još na vrlo niskom stupnju pa se pojedina kaznena djela uopće ne doživljavaju kao delikti. Kao rješenje ovog problema ističe se pravovremeno otkrivanje ovih djela i podnošenje kvalitetnih kaznenih prijava koje bi potencijalno rezultirale drugačijom strukturom donesenih odluka. Ukazuje se kao nužnost kontinuirano praćenje sudske prakse s primjerima dobre prakse iz EU. ${ }^{87}$

Prema statističkim podacima MUP-a, materijalna šteta nastala od prijavljenih kaznenih djela protiv okoliša u 2014. godini iznosila je 24.732 .158 kuna. Iznosi materijalne štete nastale kao posljedica kaznenih djela protiv okoliša jasno upućuju na opasnost i ozbiljnost ove vrste kriminala, neovisno o malom broju prijavljenih i progonjenih kaznenih djela. Tim više što, imajući na umu visoke iznose materijalne štete, sudovi ne određuju oduzimanje imovinske koristi, upitno je i ostvarenje svrhe kaznenopravnih sankcija.

85 V. Rješenje ŽS Pu Kž 342/2007-6.

86 Iz Izvješća Državnog odvjetništva Republike Hrvatske za 2013. godinu, RH DORH, Zagreb, 2014.

87 Izvješće Državnog odvjetništva Republike Hrvatske za 2014. godinu, RH DORH, Zagreb, 2015., str. 57-58. 
Tablica 1. Prijavljena i razriješena kaznena djela protiv okoliša u 2013. i 2014. g. ${ }^{88}$

\begin{tabular}{|c|c|c|c|c|c|c|c|}
\hline & \multicolumn{3}{|c|}{$\begin{array}{c}\text { Prijavljena kaznena djela } \\
\text { protiv okoliša }\end{array}$} & \multicolumn{3}{c|}{$\begin{array}{c}\text { Razriješena kaznena djela } \\
\text { protiv okoliša }\end{array}$} & \multirow{2}{*}{$\begin{array}{c}\text { Materijalna } \\
\text { šteta } 2014 .\end{array}$} \\
\cline { 2 - 6 } & 2013. & 2014. & $+-\%$ & 2013. & 2014. & $+-\%$ & \\
\hline Ukupno & 389 & 369 & $-5,1$ & 292 & 280 & $-4,1$ & $\begin{array}{c}24.732,158 \\
\mathrm{kn}\end{array}$ \\
\hline
\end{tabular}

Tablica 2. Optužene pravne osobe te pravne osobe proglašene odgovornima prema odlukama sudova i izrečenim kaznama ili drugim mjerama u 2013.

\begin{tabular}{|l|l|l|}
\hline & Ukupno & Kaznena djela protiv okoliša \\
\hline \multicolumn{1}{|c|}{ Ukupno } & 406 & 43 \\
\hline Proglašeni odgovornima & 143 & 7 \\
\hline Nisu proglašeni odgovornima & 263 & 36 \\
\hline Odbačaj & 27 & 3 \\
\hline Obustava kaznenog postupka & 144 & 25 \\
\hline Oslobađajuća presuda & 35 & 3 \\
\hline Odbijajuća presuda & 57 & 5 \\
\hline Kazne i druge mjere - ukupno & 143 & 7 \\
\hline Novčana kazna & 143 & - \\
\hline Oduzimanje imovinske koristi & 10 & 7 \\
\hline
\end{tabular}

\section{ZAKLJUČAK}

Premda statistički gledano kaznena djela protiv okoliša čine neznatan udio u ukupnom kriminalitetu, istovremeno ta kaznena djela postaju sve složenija te sve češće povezana s organiziranim kriminalom. Unatoč potencijalno teškim posljedicama kaznenih djela protiv okoliša, ozbiljnost ovih kaznenih djela još je uvijek podcijenjena, kako na nacionalnoj tako i na međunarodnoj razini. Istraživanja provođena u okviru EU ukazuju na to, a statistički podaci o ovoj vrsti kriminaliteta kod nas potvrđuju da tijela nadležna za otkrivanje, istraživanje i progon ove vrste kriminala nemaju dovoljno izraženu svijest o ozbiljnosti i opasnosti kaznenih djela protiv okoliša.

88 Izvor: Ministarstvo unutarnjih poslova, Služba za strateško planiranje, analitiku i razvoj, Statistički pregled temeljnih sigurnosnih pokazatelja i rezultata rada u 2014. godini, Zagreb, siječanj 2015., str. 3839. 
Borba protiv kaznenih djela protiv okoliša zahtijeva interdisciplinarni pristup u svim stadijima kaznenopravne reakcije države na počinjeno djelo. Jedna od temeljnih značajki i zahtjeva borbe protiv ekološkog kriminala jest specijalizacija i edukacija tijela nadležnih za istraživanje i kazneni progon kaznenih djela protiv okoliša. Bitno je da na svim institucionalnim razinama, u policiji, državnom odvjetništvu te na sudu, postoje službenici koji su educirani te pretežno usredotočeni na borbu protiv ove vrste kriminala.

Pojačanim interesom skupina organiziranog kriminala za ekološki kriminal, Europska unija je intenzivirala svoje zakonodavne i praktične aktivnosti na ovom području te su posebno značajna nastojanja Eurojusta i Europola u poboljšanju suradnje tijela kaznenog progona država članica EU te u dijeljenju i prikupljanju najbolje prakse postupanja. Ipak, treba naglasiti da ni Eurojust ni Europol nemaju ovlasti započeti kazneni progon ili istragu u državi članici već imaju ulogu koordinatora aktivnosti nadležnih nacionalnih tijela. Osim jačanja policijske i pravosudne suradnje, države članice EU trebaju intenzivno raditi na usklađivanju svog zakonodavstva s EU zakonodavstvom na području zaštite okoliša, pogotovo u pogledu kaznenopravnih sankcija budući da neusklađenost u pogledu težine sankcija za pojedina kaznena djela može ugroziti međunarodnu suradnju.

Za otkrivanje, istraživanje i progon kaznenih djela protiv okoliša potrebno je, osim zakonodavnog okvira, osigurati institucionalne i organizacijske pretpostavke. $\mathrm{U}$ tom pogledu potrebno je ulaganje dodatnih materijalnih sredstava, ali ona ne mogu sama po sebi povećati učinkovitost kaznenih progona ako se borba protiv ove vrste kriminaliteta ne odredi kao prioritet.

\section{INVESTIGATION AND PROSECUTION OF ENVIRONMENTAL CRIME}

This paper analyzes the issues related to the prosecution and investigation of environmental crime, especially in terms of legislative and practical activities of the EU bodies, Eurojust and Europol, in the field of legal protection of the environment. The legislative framework for environmental crime is extensive, complex and often of a technical nature and requires expertise and specialized knowledge of the prosecuting authorities in all stages of criminal proceedings. There are difficulties in detecting environmental crimes and in proving those crimes. Although Croatian criminal legislation sets a high level of environmental protection, there is lack of awareness leading to underestimation of this type of crimes. At EU level there is a need for better and more coordinated cross-border cooperation. The two prosecutorial networks - the ENPE and IMPEL - are very active in the field of environmental crime, inter alia, through the involvement and availability of independent experts for investigations and prosecutions. 